\title{
IRON-OXIDE MINERALIZATION OF SESI, KOROPI (S. HYMITTOS, GREECE): MINERALIZATION WITHIN A DETACHMENT ZONE
}

\author{
Stouraiti C. ${ }^{1}$, Lekkas S. ${ }^{2}$, Lozios S. ${ }^{2}$ and Kanellopoulos C. ${ }^{3}$ \\ ${ }^{1}$ Department of Geology and Geoenvironment, Division of Economic Geology and Geochemistry, \\ National and Kapodistrian University of Athens, Panepistimiopolis, Ano Ilissia, Athens 15784, \\ Greece, chstouraiti@geol.uoa.gr \\ ${ }^{2}$ Department of Geology and Geoenvironment, Division of Dynamic Tectonic and Applied \\ Geology, National and Kapodistrian University of Athens, Panepistimiopolis, Ano Ilissia, Athens \\ 15784,Greece, slozios@geol.uoa.gr \\ ${ }^{3}$ Institute of Geology and Mineral Exploration, $1^{\text {st }}$ Spirou Louis St., Olympic Village, 13677, \\ Acharnae, Greece, ckanellopoulos@gmail.com
}

\begin{abstract}
Small occurrences of iron-oxide deposits at Sesi-Koropi in S. Hymittos, are hosted by an extensional brittle detachment zone between carbonate rocks of "Vari-Kirou Pira" and "Hymittos" units. Another low-angle fault separates a heterogeneous formation of schists, containing meta-ophiolitic blocks ("Lavrion" Unit), which is cut by high-angle normal faults that root in the detachment zone, reducing the total structural thickness of "Hymittos" marbles and bringing in contact the meta-ophiolitc lithologies with the "Vari-Kirou Pira" dolomites. Three mine caves were found along the detachment zone indicating that these iron deposits were possibly mined on a very small scale in the past. The mineralization is developed in a cataclastic zone a few meters thick (3-5m), forming thin rusty black encrustations and larger zones of alteration with a reddish to yellow brown hue. Scanning Electron Microscope (SEM) mineralogical study of the iron-ore deposit indicated that hematite is the primary iron-oxide mineral extensively replaced by goethite. Goethite appears with the typical colloidal form within voids showing typical open-space filling type microstructures. According to field evidence and the tectonic macro-structure of the area, the mineralization is associated with hydrothermal fluid circulation along the brittle detachment zone between meta-ophiolitic lithologies and carbonate rocks. Similar type iron-oxides mineralization in cataclastic zones were observed along other detachment zones in northern and southeastern Hymittos Mt. and further south towards Lavrion. This suggests that this type of mineralization is not local but has a broader development and regional implications for the tectonic evolution of the central and SE Attica.

Keywords: iron-oxides, hematite, goethite, mineralization, brittle detachment zone, low-angle fault.
\end{abstract}

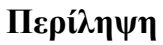

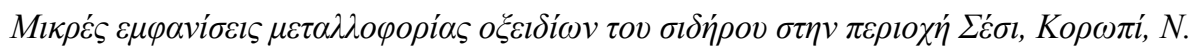

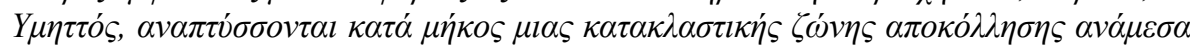

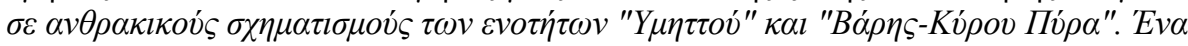




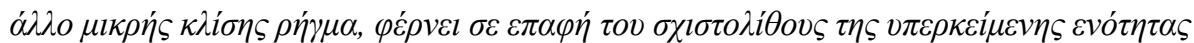

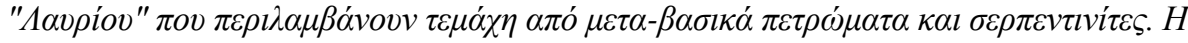

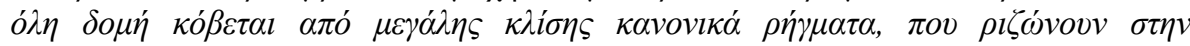

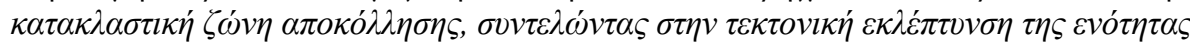

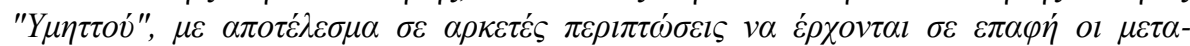

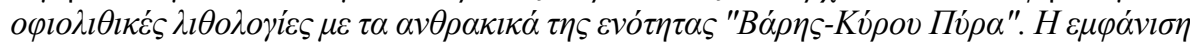

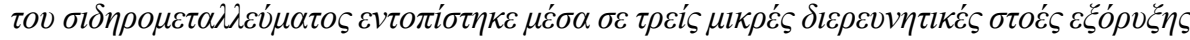

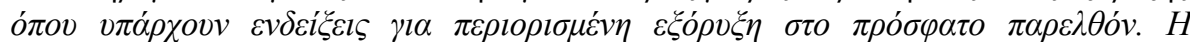

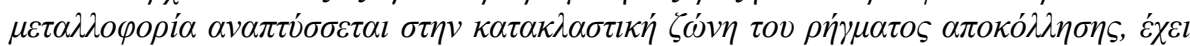

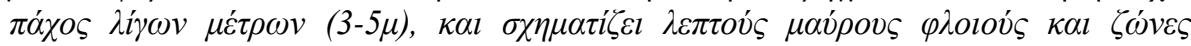

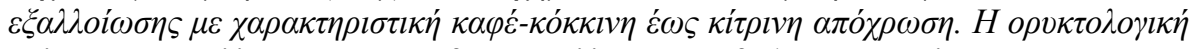

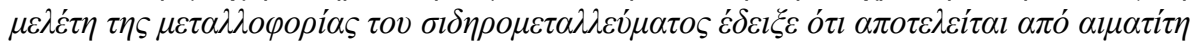

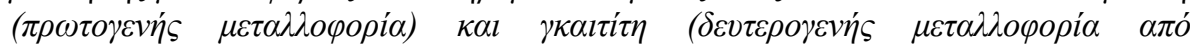

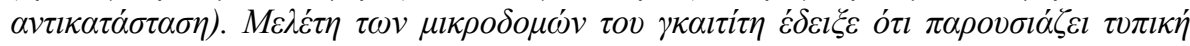

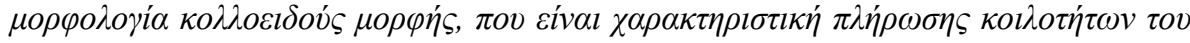

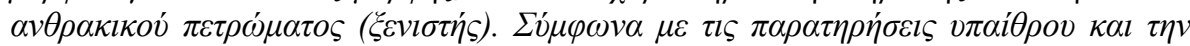

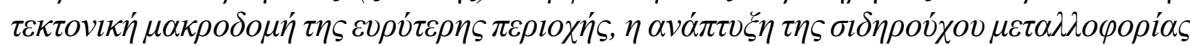

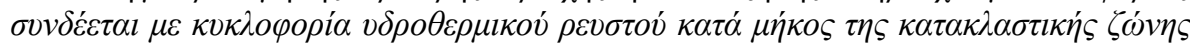

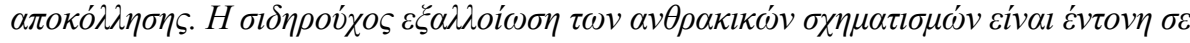

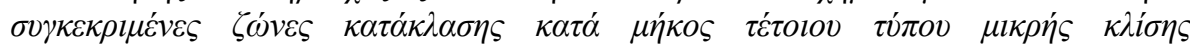

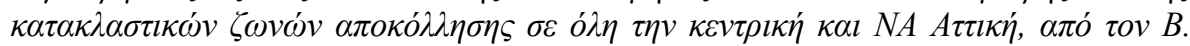

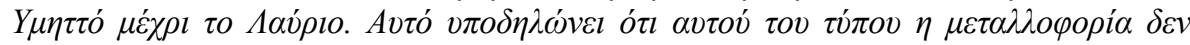

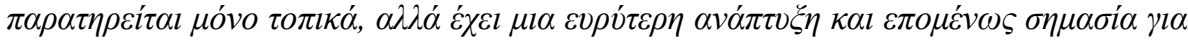

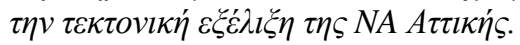

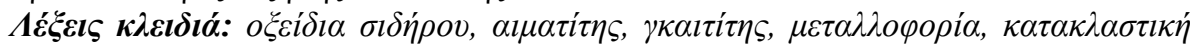

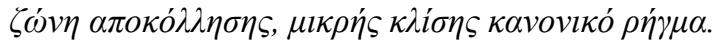

\section{Introduction}

This study describes for the first time, the occurrence of an iron-oxide deposit in the Sesi area, south Hymittos Mt., along the brecciated contact of the "Lower Marble" ("Hymittos" Unit) with the underlying dolomitic marbles ("Vari-Kirou Pira" Unit). Oxidized mineralization related to brittle detachment faulting (low-angle normal faults), having characteristic structural features as well as mineral assemblage, have recently been recognized in many cases in the Attic Cycladic massif, from Lavrion to western Cyclades and further south in western Crete (Lavrion: Berger et al, 2013; Kea: Rice et al., 2012; Kithnos, Serifos: Grasemann et al., 2012; W Crete: Seidel et al., 2005). Similar iron-oxide deposits associated with detachment faulting in western Crete have been correlated, by Seidel et al. (2005) with the extension model of Basin and Range Province in the western United States. Previous authors (Seidel et al., 2005) suggested that this type of mineralization may be an indication of deep crustal fluid flow resulting from retrograde metamorphism in hot lower plate rocks. Alternatively, it may represent low-temperature circulation of fluids at shallower crustal levels.

In some of the above mentioned cases of detachment-related mineralizatiosn there is a strong localization of detachment faulting and interaction of brittle deformation with the injection of fluids related to granitoid intrusions (e.g. Lavrion, Serifos). In south Hymittos Mt. (Sesi-Koropi) small iron oxide deposits are also located within a detachment zone and hosted by carbonate rocks. However, the origin of the lower temperature Fe-mineralization (e.g. Kea and Sesi-Hymittos Mt.) is not straight-forward and remains speculative regarding the heat source that triggered hydrothermal circulation and Fe-oxide deposition at the upper crustal levels.

Here we report mineralogical and petrographic data of the iron-ore samples which allow categorization of goethite into different textural types and make a preliminary examination of its possible origin. Moreover, in order to understand the interrelations between the mineralization and the detachment tectonics, a detailed geological mapping of the Sesi area was carried out and the 
project will continue on other key areas in Hymittos Mt and southern Attica, where both detachment structures and Fe-oxide mineralization are spatially closely associated.

\section{Geological Setting}

The Hymittos Mt. (located to the east of Athens) belongs to the Attic-Cycladic crystalline massif (ACCM), which in turn belongs to the Intermediate Tectonometamorphic Zone of the Hellenides orogen (Dürr, 1978 and Papanikolaou, 1988). Lepsius (1893) was the first to propose a complete lithostratigraphic structure of Attica, which is nowadays accepted with some alterations. Marinos and Petrascheck (1956), for the first time and Katsikatsos $(1977,1990)$ later, suggest the existence of two main geotectonic units in Attica - one relative autochthonous and an allochthonous - and prove that all metamorphic rocks of south and central Attica are both of Mesozoic age.

Based on systematic mapping and detailed litho-stratigraphic correlations, Lekkas and Lozios (2000) proposed a refined model of the tectonic structure of Hymittos Mt., by integrating all previous structural and petrological data for the area (Fig. 1). According to these authors, from bottom to top the structural sequence of Hymitos Mt. consists of: a) the lower "Vari-Kirou Pira" Unit, b) the overlying "Hymittos" Unit (both represent the relative autochthonous of Marinos and Petrascheck, 1956 and Katsikatsos, 1977) and c) the allochthonous "Lavrion-Athens" Unit.

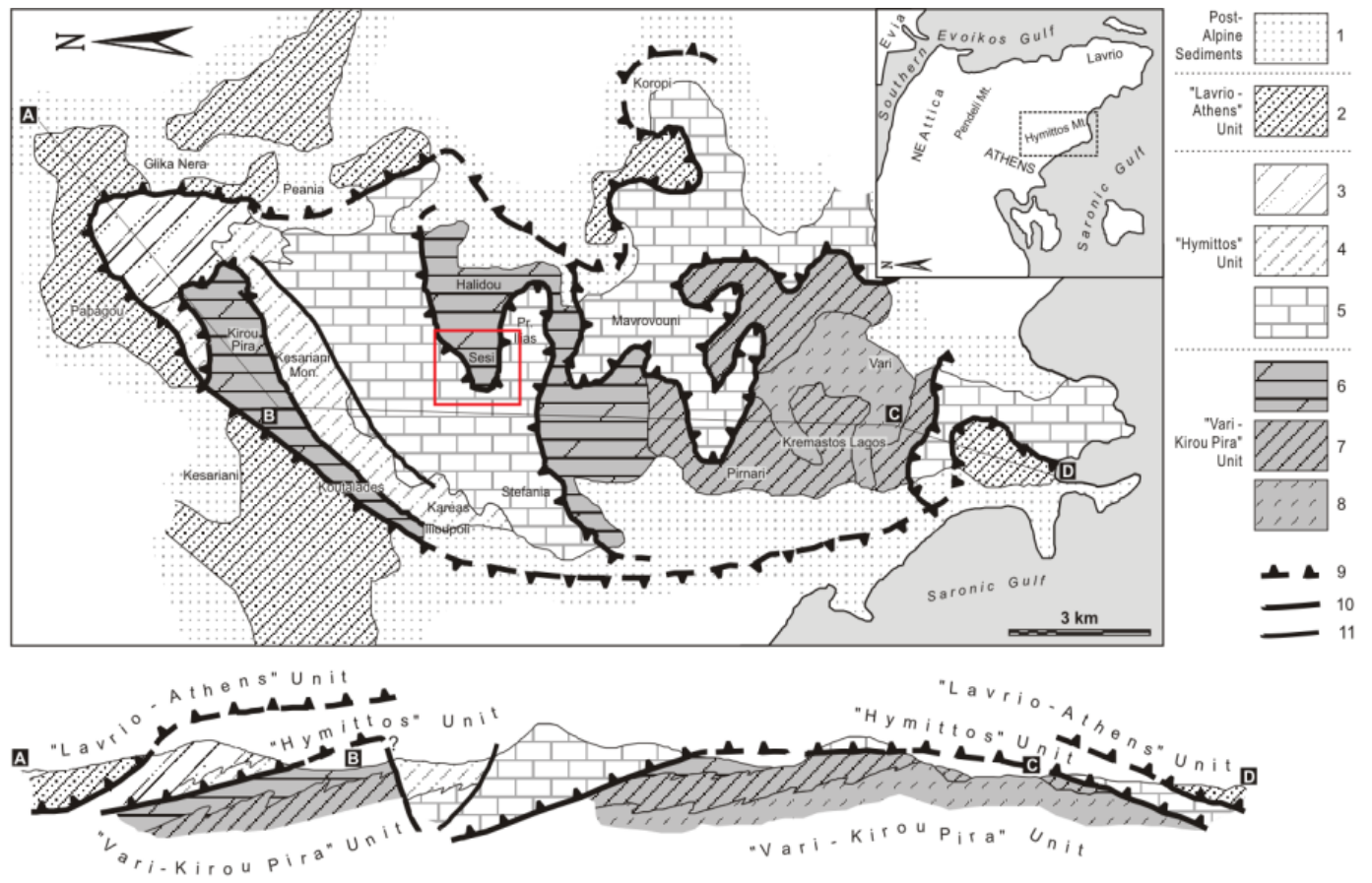

Figure 1 - Simplified geological map of Hymittos Mt., after Lekkas and Lozios (2000), showing the area of study in the red colored frame. 1: post-alpine sediments, 2: "LavrionAthens" Unit, 3, 4 and 5: "Hymittos" Unit (3: marble and alternations of marble and schists, 4: "Kessariani Schists", 5: "Lower Marble"), 6, 7 and 8: "Vari-Kirou Pira" Unit (6: white massive dolomite, 7: impure dolomite marble, 8: "Vari Schist"), 9: brittle detachment, 10: tectonic contact, 11: fault.

The lower "Vari-Kirou Pira" Unit consists of the following litho-stratigraphic units, from base to top (Fig. 1): a) calc- and micaschists (equivalent to "Vari Sshists" of Lepsius, 1893), b) an intermediate horizon of grey to black, thin-bedded impure dolomitic marble and c) an upper thick 
horizon of white massive dolomitic marble (equivalent to "Pirnari Dolomite" of Lepsius). The latter unit crops out at central Hymittos (including the study area of Sesi) (Fig. 2).
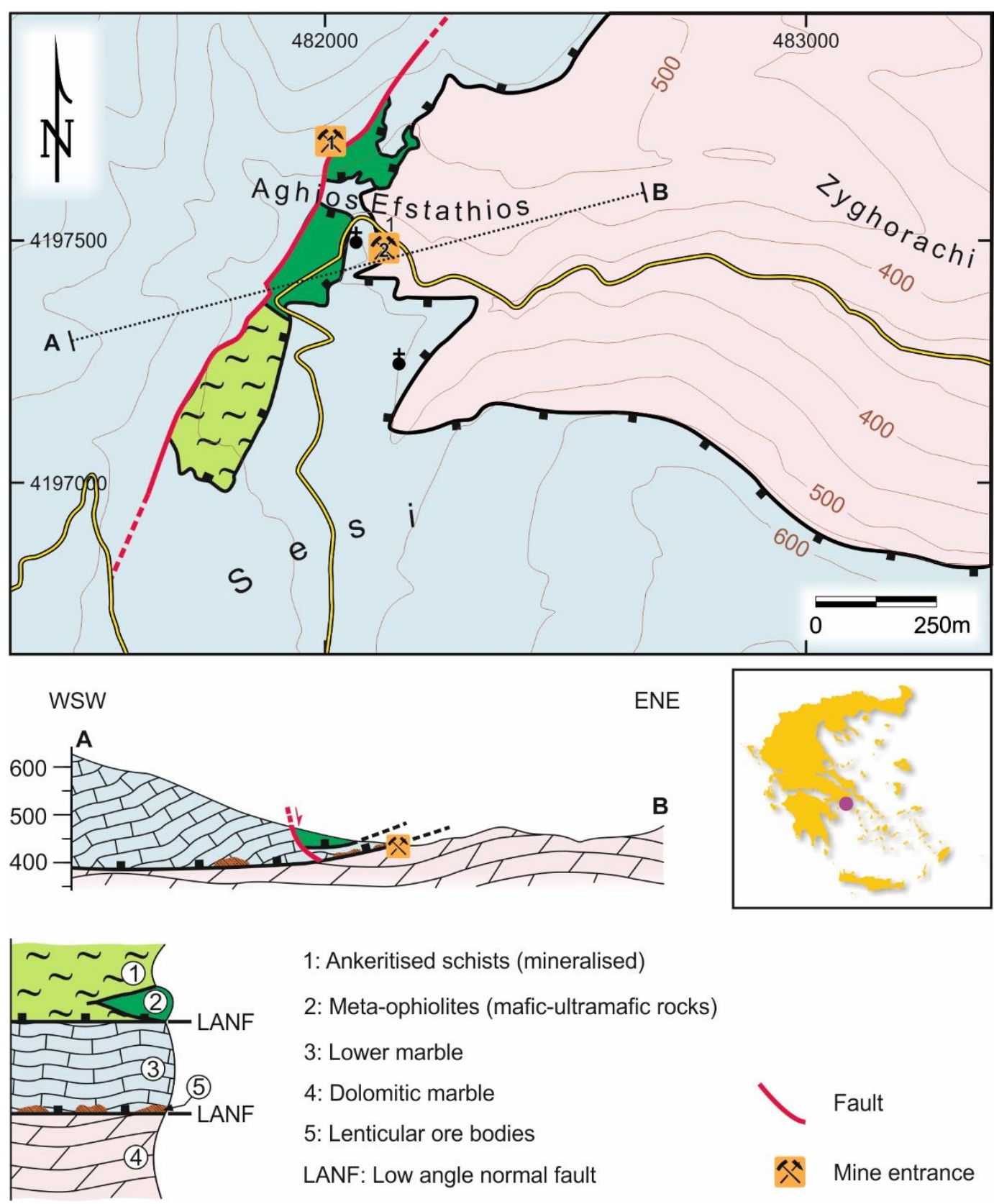
1: Ankeritised schists (mineralised)
2: Meta-ophiolites (mafic-ultramafic rocks)
3: Lower marble
4: Dolomitic marble
5: Lenticular ore bodies
LANF: Low angle normal fault

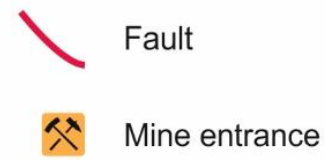

Figure 2 - Detailed geological map of Sesi area, Koropi, central Hymittos. Location of mine caves close to the tectonic contact of Lower Marble with the underlying dolomites, are shown with numbers $(1,2)$ and cross section $A-B$ is also shown.

The overlying "Hymittos" Unit, consists of the following tectonostratigraphic succession, from base to top: a) white, light blue or grey, massive to thick-bedded marble (equivalent to the "Lower Marble" of Lepsius), outcropping at central and northern Hymittos Mt. (including the study area of Sesi), b) a continuous sequence of various types of schists (mica-, calc-, epidote-chlorite and actinolite schists) alternating with quartzites, cipolines and thin marble horizons (equivalent to 
"Kessariani Schists" of Lepsius) including also blocks of meta-basic rocks and serpentinites and c) dark blue or grey marbles and impure marbles including a lot of intercalations of calc- and micaschists. This formation outcrops at the northernmost of Hymittos Mt.

The upper "Lavrio-Athens" Unit is a very heterogeneous formation including mainly schists or phyllites, as the predominant lithology, alternating with quartzites, dark coloured marbles, impure marbles and marbles with silex, dark thin-layered marbles, crystalline limestones and variable size blocks of metabasic rocks and serpentinites, giving the "chaotic" image of a tectonic melange. This unit mainly located around the flanks of Hymittos Mt., although relics of schists, serpentinites and metabasic rocks found along the central axis of the mountain, as in the study area of Sesi (Fig. 2).

According to the same authors the above mentioned tectonic units are separated by brittle low-angle normal faults (or brittle detachment zones) and the overall tectonic macrostructure of Hymittos Mt. corresponds to a km-scale very gentle anticlinical macro-fold or dome (with a N-S main axis), where the core of this dome consists of the lower "Vari-Kirou Pira" tectonic unit (Fig. 1). The most impressive low-angle fault is the lower one, where the sharp and geometric contact between the "Lower Marble" of "Hymittos" Unit (hanging wall) and the dolomitic marbles and impure marbles of "Vari-Kirou Pira" Unit (foot-wall) outcropped in many places, along the E-W gorges and small valleys that cross the mountain, mainly at the central part (e.g. the study area of Sesi), or more to the south (e.g. Ano Glifada-Terpsithea). The other (upper) low-angle normal fault brings together the various lithologies of "Lavrio-Athens" Unit (hanging wall) with the "Lower Marble" or "Kessariani Schists" of "Hymittos" Unit (foot-wall), outcropping mainly along the western or eastern flanks of Hymittos Mt. Younger high-angle normal faults cut this upper low-angle fault and root in the lower detachment zone, producing tilting of the hanging wall fault-blocks and reducing the total structural thickness of "Lower Marble". A result of this is to bring in contact the lithologies of the "LavrionAthens" Unit (including the meta-ophiolitc blocks) with the lower detachment zone and the dolomitic marble, as in the case of Sesi area (Fig. 2).

The cataclastic rocks of this lower detachment forming up a brittle zone of few meters thick (3-5 m) (Fig. 3). It is characterised by reddish tectonic breccias, including marble and rarely dolomitic clasts and producing cargneule formation which mark the marble (hanging wall) and the dolomitic marble (foot wall) adjacent to the contact. It is within this tectonic zone that small iron-hydroxide deposits have been identified in the area of Sesi (south Hymittos) and described herein for the first time (Fig. 4). Recent exploration and small scale mining activity in the study area is evidenced by three small galleries, bearing traces of excavation and drilling with modern instrumentation.

\section{Iron-oxide mineralization}

The mineralization in the study area occurs mostly along foliation plains within a brecciated zone of the carbonate host rocks, of variable thickness (1m up to $3 \mathrm{~m}$ ) (Fig. 3). Iron-oxide mineralization consists mainly of goethite.

Hematite has a subordinate and relic occurrence within the goethite matrix. Goethite forms porous hard crusts within the carbonate host rock. In the study area of Sesi, massive hematite/goethite mineralization forms lenses of up to $0.5 \mathrm{~m}$ thick. The goethite (initially hematite) itself, is brecciated and surrounded by a matrix of fine-grained goethite (Fig. 3, 4).

Gangue minerals are mostly calcite (Table 1) and minor aluminosilicates. Traces of barite and base metal sulfides, sphalerite, galena (sample M-2), and chalcopyrite (sample CS15-M1-B) were identified only by Scanning Electron Microscopy analysis, as very fine grains within voids of massive goethite samples (see section below). 

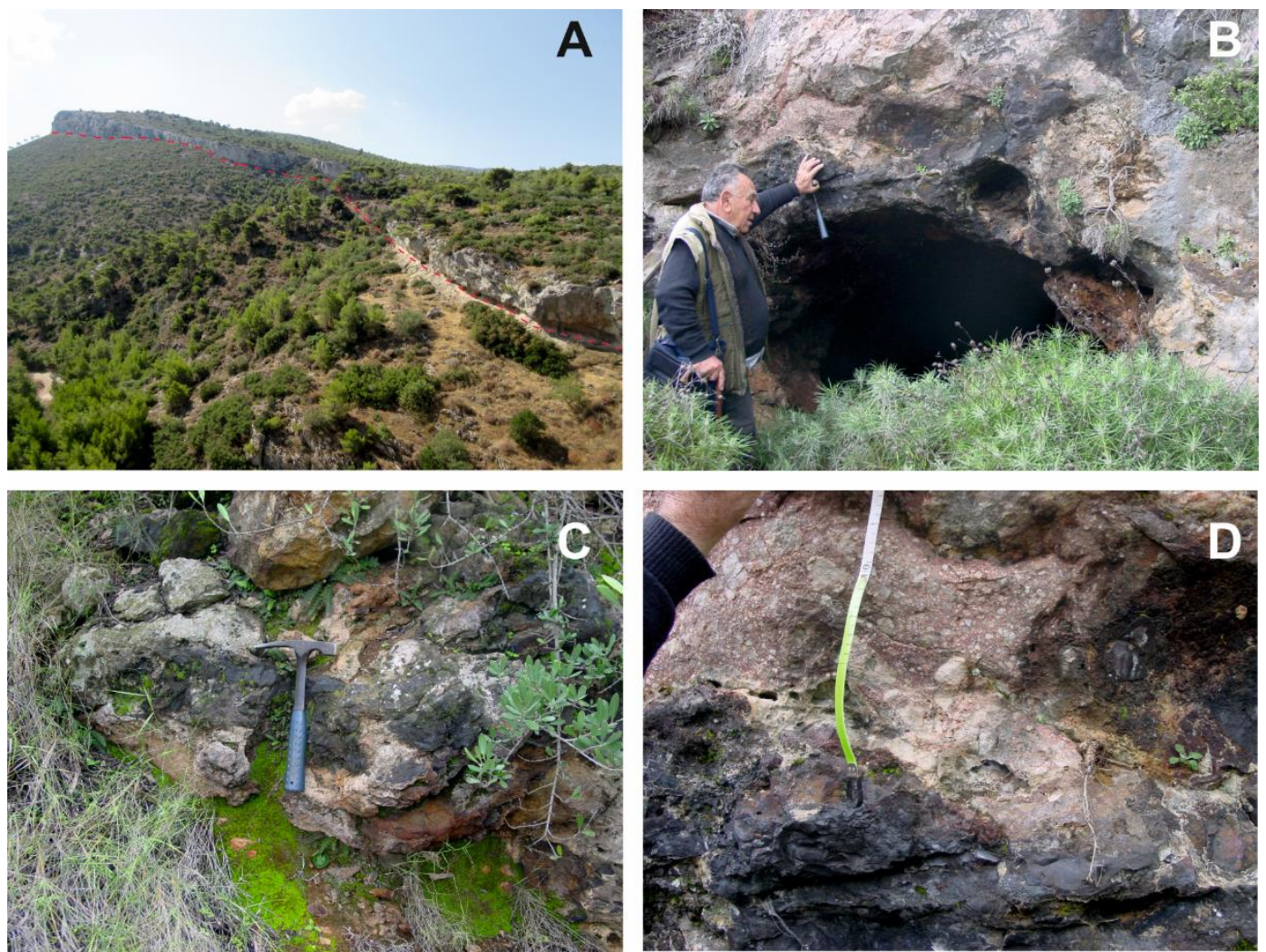

Figure 3 - Field photos from the Sesi area (S. Hymittos), showing: (A) the low-angle normal fault (brittle detachment, in red-dashed line) separating the "Lower Marble" (hanging wall) and the dolomitic marble (foot-wall). (B) Fe-ore (hematite) occurrence in the small mining excavations along the detachment zone. (C) Surface outcrop of Fe-ore encrustations within the carbonate host rock (locality 1 of map Fig. 2). (D) Detail of Figure B (center-left) showing brecciated zone of the carbonate host, fragments of Fe-ore (dark brown-black) and matrix filled with goethite.

The carbonate host rock (pure and dolomitic marble) is strongly altered due to fluid-rock interaction along the detachment zone as evidenced by the highly porous and a brown coloration. The host rocks are extensively impregnated by limonite which causes a ubiquitous yellow-brown hue. Goethite from the study area has been examined in terms of its morphology and microstructure in relation to chemical composition. Scanning electron microscopy study indicated several goethite morphotypes.

\section{Materials and Methods}

\subsection{Sampling}

Sampling of Fe-ore from breccias as well as, of the marble host rocks was carried out. Representative samples were collected from three exploratory cavities in the Sesi area. Sampling locations are shown in the detailed map of Figure 2.

\subsection{Analytical methods}

The mineralogy of the oxidized Fe-ore was studied by conventional X-ray diffraction (XRD) techniques on bulk samples and Scanning Electron Microscopy (SEM) on thin sections. XRD analyses were carried out at the University of Athens (Geology Dept.), using a Siemens D-5005 diffractometer with $\mathrm{Cu} \mathrm{K}_{\text {_ }}$ radiation. 


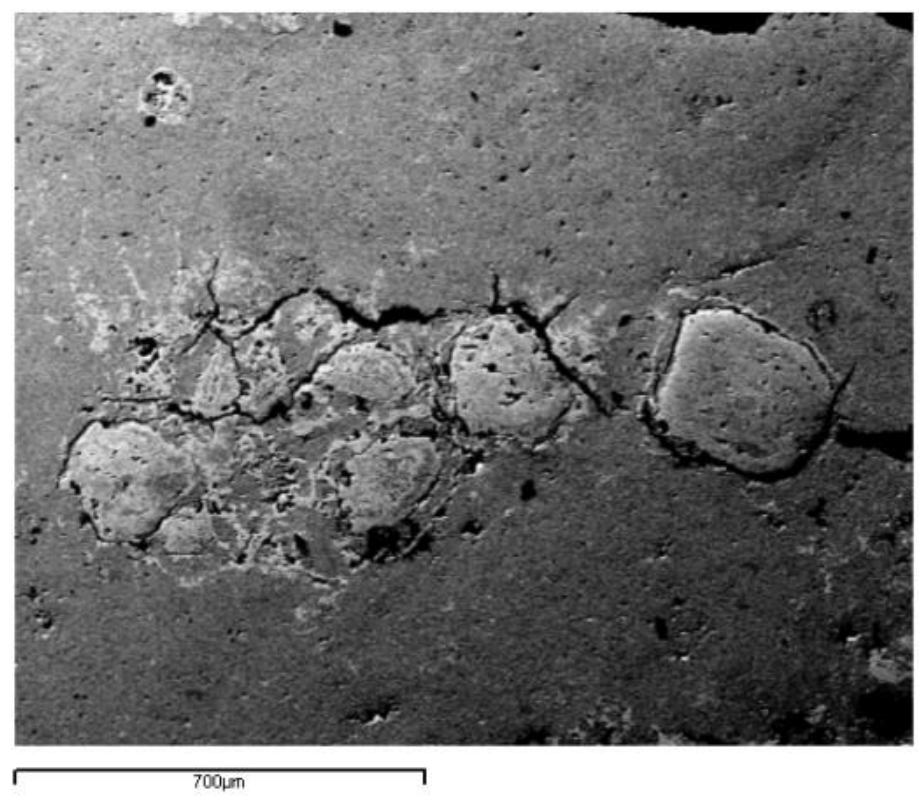

Figure 4 - Electron micro-photographs of brecciated iron oxides: fragments of goethite (with relic hematite, in light grey color) in a very fine grained matrix of goethite [sample M-2(9)].

SEM analyses and electron micro-photographs were conducted using a JEOL JSM-5600 scanning electron microscope (SEM) in energy-dispersive mode (EDS) in order to obtain semi-quantitative analysis [Institute of Geological and Metallurgical Exploration - Athens, (IGME)]; running acceleration voltage at $15 \mathrm{kV}$. The study utilized semi- quantitative analysis using appropriate standards.

\section{Results}

XRD analysis of the ore samples revealed (Fig.5) that the major iron bearing mineral is goethite followed by hematite. The other gangue minerals identified are calcite $(\mathrm{CaCO} 3)$. Traces of Barite (BaSO4) and aluminosilicates were identified only by SEM analysis.

\subsection{Characteristics of goethite}

Goethite samples were examined by scanning electron microscopy (SEM) and analyses were obtained on a semi-quantitative basis. Different types of goethite morphology have been distinguished in the Sesi Fe-ore formation. These are botryoidal, spheroidal and massive (Fig. 6). Some microanalytical differences among these morphologies were observed on the basis of $\mathrm{Fe}$ content of goethite (see Table 1).

\subsection{Microstructures}

The microstructures of goethite can be broadly categorized mostly as open space filling type (Fig. 6). Open space filling textures (Fig. 6) indicate shallow depths of formation, where brittle rocks deform by fracturing. Fe-enriched fluids circulate freely within fractures and precipitate along with gangue constituents during sudden changes in pressure/temperature. 


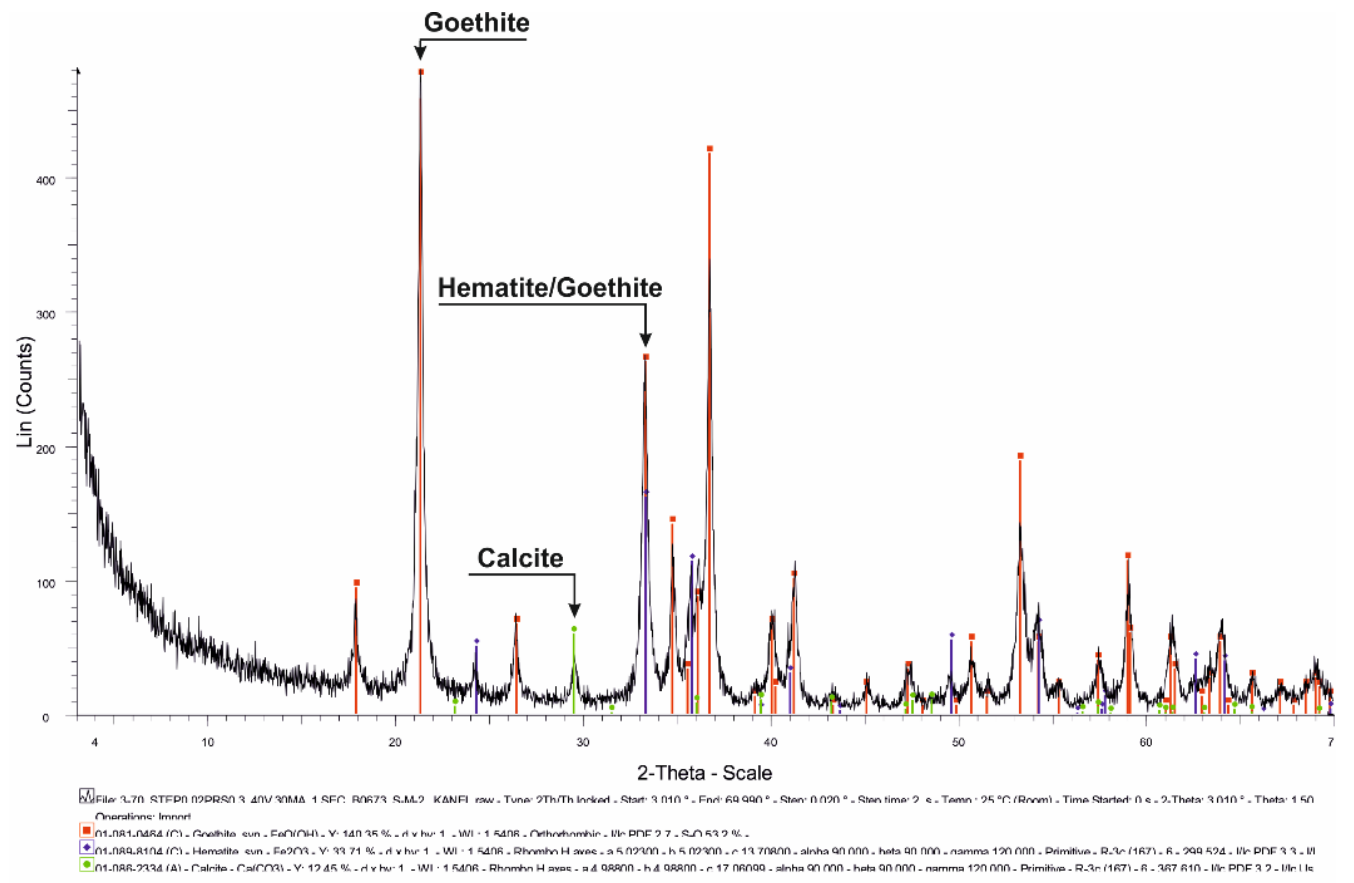

Figure 5 - Evaluated XRD pattern of representative Fe-ore samples from the Sesi area (S. Hymittos). The major peaks of the main mineral phases are underlined and shown in order of abundance: goethite, hematite calcite.

The most typical form of this type is the colloform texture which occurs as rhythmic concentric thin layers of goethite in different shades (Fig. 6C). Different grey colored layers in the SEM images (photomicrographs, Fig. 6) are due to slight difference in iron content (Table 1). Moreover, thin encrustations of goethite lining a cavity and small beads of goethite are common types of open space fillings in the Sesi iron-ore formation.

Evidence for replacement type textures is not common. In most cases, hematite grains appear cracked, weathered and almost completely replaced by goethite, where only an outline of the original Fe-oxide is seen. Replacement is more common at high temperature, where open spaces are very limited. The fact that there is scant evidence for remaining replacement texture indicates for the low temperature of formation of the Sesi iron-ore.

\subsection{Compositional variations between various types}

The different morphology of goethite in terms of Fe (wt.\%), as obtained using SEM microanalysis, are given in Table 1. Results show relative compositional variation between these types.

The botryoidal and reniform morphotypes of goethite are the more iron rich types (av. Fe is 75 wt.\%). The colloform type and the massive porous type (limonite) are the less enriched in Fe content. Other elements, commonly adsorbed in goethite mineral, such as Al, Si, P and Mn were not detected in goethite samples by SEM analysis.

\section{Discussion}

Evidence for ferruginous alteration along the detachment zone between the "Lower Marble" (of "Hymittos" Unit) and the underlying dolomitic marbles (of "Vari-Kirou Pira" Unit) is widespread along the entire contact from the central Hymittos Mt. to Ano Glyfada (Lekkas and Lozios, 2000) and further south to Panion hill (Bassi et al., 2004), indicating that this characteristic zone is not local but has a regional development. However, associated small Fe-oxide deposits along this zone 
are described, for the first time in the Sesi area. This observation came into light after detailed mapping. According to microscopic observations, the iron-ore development in the area of Sesi exhibit open space filling textures and extensive fracturing of the primary Fe-oxide mineralization (Fig. 6). Such textures indicate shallow depths of formation, where brittle rocks deform by fracturing. Fe-enriched fluids circulate freely within fractures and precipitate along with gangue constituents during sudden changes in pressure/temperature.
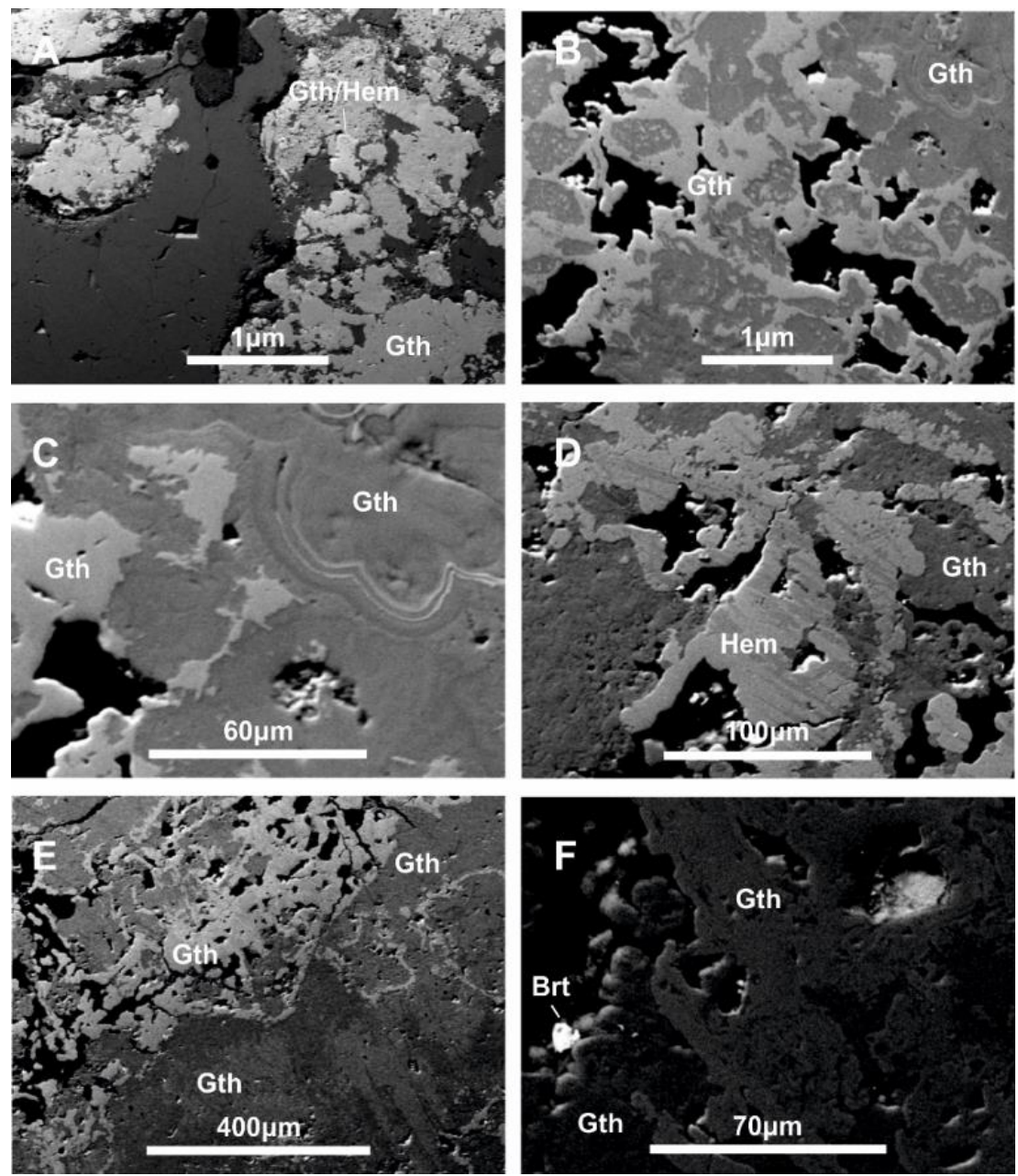

Figure 6 - Electron photo micropgraphs showing different microstructures of goethite developed as open space filling. (A) Amorphous Goethite (Gth) occupying the pore spaces of the carbonate host rock. Relic hematite (noted as Gth/Hem) occurs as lighter colored areas [sample CS15-M1-A(1)]. (B) Goethite (Gth) filling open space of the carbonate host. Lighter grey edges of goethite mass are richer in iron content than dark grey matrix [CS15-M1A(4)]. (C) Alternate colloform layers of goethite forming thin laminations. Different grey colored layers are due to slight difference in iron content (see text for detail). The layers have

different thickness and reflectivity [CS15-M1-A (5)]. (D) Botryoidal form (center) of hematite (Hem) and smaller beads (bottom) of goethite in a matrix of goethite (Gth) [CS15M2(5)]. (E) Goethite forming in two generations, a dark grey matrix (Fe-poor) and light grey goethite filling the porous area (Fe-rich) $[\mathrm{M}-2(6)]$. (F) Porous goethite matrix and barite crystal (Brt) forming in the void [M-2 (15)]. Thin encrustation of goethite (Gth). Abbreviations from Whitney and Evans (2010). 
Table 1 - Elementary goethite compositional variation from the Sesi iron-oxide deposit and associated minerals through SEM - EDS semi-quantitative analyses (wt\%).

\begin{tabular}{|c|c|c|c|c|c|}
\hline & Sample no. & $\mathrm{Fe}(\mathrm{wt} \%)$ & $O(w t \%)$ & $\begin{array}{c}\text { Subtotal } \\
\left(\mathrm{Fe}_{2} \mathrm{O}_{3} \text { wt. } \%\right)\end{array}$ & Morphology \\
\hline \multicolumn{6}{|c|}{ Goethite/Hematite } \\
\hline 1 & M-2 (3)-2 & 74.16 & 21.24 & 95.40 & Light colored diffuse areas $(\mathrm{Hem})$ \\
\hline 2 & M-2 (5)-1 & 77.90 & 22.32 & 100.21 & Botryoidal $(\mathrm{Gth} / \mathrm{Hem})$ \\
\hline 3 & M-2 (2)-3 & 71.70 & 20.54 & 92.24 & Light colored patches in goethite \\
\hline 4 & M2 (16)-2 & 75.95 & 21.76 & 97.71 & lining cavities \\
\hline 5 & CS-15-M1A (3) & 71.50 & 20.50 & 92.00 & Light colored patches (reniform) \\
\hline 6 & CS-15-M1A (1) & 70.94 & 20.32 & 91.26 & Light colored patches \\
\hline 7 & CS-15-M1A (5)-1 & 71.32 & 20.43 & 91.76 & Light colored patches \\
\hline 8 & CS-15-M1A (7)-1 & 70.46 & 20.18 & 90.64 & Light colored patches \\
\hline 9 & CS-15-M1A (7)-3 & 67.80 & 19.42 & 87.22 & Light colored patches \\
\hline 10 & CS-15-M1A (7)-4 & 66.20 & 19.14 & 85.96 & Light colored patches \\
\hline 11 & CS-15-M1A (8)-4 & 69.56 & 19.93 & 89.49 & Light colored edge of encrustation \\
\hline 12 & CS-15-M1-B (3)-1 & 67.97 & 19.47 & 87.45 & Light colored areas within goethite \\
\hline \multicolumn{6}{|c|}{ Goethite Colloform layers } \\
\hline 13 & CS-15-M1A (2) & 62.31 & 18.55 & 80.86 & Layer \\
\hline 14 & CS-15-M1A (2) & 68.86 & 19.73 & 88.58 & Layer \\
\hline 15 & CS15-M1A (10)-4 & 62.29 & 17.85 & 80.14 & Massive grey matrix (Goethite) \\
\hline 16 & CS15-M1A (9)-3 & 61.59 & 17.64 & 79.23 & Massive grey matrix \\
\hline 17 & CS15-M1A (7)-5 & 62.14 & 17.18 & 79.94 & Massive grey matrix \\
\hline \multicolumn{6}{|c|}{ Goethite/Limonite matrix } \\
\hline 18 & CS15-M1A (7)-6 & 59.33 & 17.00 & 76.32 & Porous matrix of carbonate host (Limonite) \\
\hline 19 & CS15-M1A(7)-7 & 50.31 & 15.84 & 66.15 & Porous matrix of carbonate host (Limonite) \\
\hline 20 & CS15-M1A (7)-2 & 59.74 & 17.14 & 76.86 & Porous matrix of carbonate host (Limonite) \\
\hline 21 & CS15-M1B (4) & 59.01 & 17.01 & 76.02 & Porous matrix (Limonite) of Fe-ore \\
\hline 22 & CS15-M1B(10)-2 & 57.59 & 16.5 & 74.08 & Grey porous matrix of Fe-ore \\
\hline \multicolumn{6}{|c|}{ Other minerals } \\
\hline & & Ba (wt\%) & $\mathrm{S}(\mathrm{wt} \%)$ & $O(w t \%)$ & Total \\
\hline 1 & M-2 (8)-1 & 58.34 & 15.050 & 30.03 & Barite grain in void \\
\hline 2 & M-2 (15)-1 & 57.00 & 16.00 & 31.08 & Barite grain in void \\
\hline
\end{tabular}

The ore mineralogy (hematite), the prominent structural control and the distinctive suite of minor elements e.g. $\mathrm{Zn}, \mathrm{Pb}, \mathrm{Cu}, \mathrm{Co}, \mathrm{Ag}$ (preliminary data) classify this deposit into the category of IronOxide Copper Gold hydrothermal deposits (IOCG) (Barton and Johnson, 2004). Similar type mineralization of Fe-oxide ore with barite along detachment zones have been recorded in almost all western Cyclades (Kea, Kythnos, Serifos) by Graseman et al. (2012). Rice et al. (2012) reported for the Kea detachment related mineralization that fluid infiltration processes particularly affected the porous parts of the detachment zone, where many of the cataclastic carbonate rocks have been strongly ankeritised. In the latter case deposition of $\mathrm{Fe}-\mathrm{Mn}-\mathrm{Pb}-\mathrm{Au}$ ores occur along brittle/ductile to brittle high-angle faults (Rice et al., 2012) and have been correlated to unexposed magmatic activity, as in the Lavrion mining district of Attica (Skarpelis, 2007; Skarpelis et al., 2008; Voudouris et al., 2008a,b and Bonsall et al. 2011). 
The underground occurrence of the Fe-ore deposits within the carbonate host rocks indicate that similar type deposits may be hidden all along the detachment zone in south Hymittos Mt. Hence systematic and thorough investigation should be carried in the future.

In the Attic Cycladic Massif evidence for fluid infiltration of hot Fe-rich fluids during and after greenschist facies metamorphism (M2) has been documented in different Cycladic islands, strongly affecting the country rock (e.g Kea: Rice et al., 2012; Serifos: Grasemann et al., 2012; Mykonos: Menant et al. 2013). In the case of Kea (e.g. Aghios Theodhoros), Rice et al. (2012) reported that iron deposits (hematite mineralization) were large enough to be mined on a very small-scale and are also associated with barite deposits.

In the case of Sesi the restricted occurrence of iron-oxide deposits (south Hymittos) and the scant occurrence of barite and base metal sulfide mineralization do not allow correlations to the Lavriontype mineralization. The meta-ophiolitic rocks which immediately overly the marble formation ("Lower Marble") and bear widespread Fe-mieneralization, could be a potential local source for the iron mineralization. However, this suggestion remains speculative and further research should be carried out in order to make regional scale correlations of the detachment related mineralization of southern Attica.

\section{Conclusion}

Field evidence and mineralogical study of the small Fe-oxide deposits of the Sesi, Koropi, S. Hymittos, revealed that mineralization is structurally controlled and developed along a brittle detachment zone (low-angle normal fault). The mineralogical study showed that the mineralization consists mainly of goethite, with subordinate hematite. Several types of microstructures of goethite formation are recognized. These are broadly grouped as open space cavity-filled types: Botryodal, cavity-line and reniform.

The source of iron and the conditions of ore formation remains speculative and needs further investigation. The observations substantiate replacement of hematite by goethite due to oxidationhydration processes at shallow crustal levels and secondary substantial open space filling within fractured and porous carbonate host.

Fluid interaction of the iron-enriched fluid with the carbonate rocks along the detachment zone and brecciation of goethite itself, indicates a structural control on the ferrigenous alteration and iron-ore formation. The ferruginous alteration of the carbonate rocks along the detachment zone is evidenced by their transformation to porous ankeritic carbonates and an extensive limonite impregnation.

\section{Acknowledgments}

We would like to thank Dr G. Oikonomou from IGME for his collaboration with SEM facility. The authors would also like to thank Dr. Sofia Pasa (IGME) for her assistance with microphotographs.

\section{References}

Bassi, E.K., Soukis, K. and Lekkas, S., 2014. The presence of Vari - Kirou Pira Unit at Panion Hill (SE Attica, Greece), Bulletin of the Geological Society of Greece 34, Proc. of the X International Congress, Thessaloniki, Greece, 1608-1617.

Bakopoulou, A., 2004. Kinematic and dynamic analysis of the tectonic contacts of Mt. Hymittos. Dissertation thesis, National and Capodistrian University of Athens, $188 \mathrm{pp}$.

Berger, A., Schneider, D., Grasemann, B. and Stockli, D., 2012. Footwall mineralization during Late Miocene extension along the West Cycladic Detachment System, Lavrion, Greece, Terra Nova, 25(3), 181-191, doi: 10.1111/ter.12016.

Bonsall, T.A., Spry, P.G., Voudouris, P., Seymour, K.St., Tombros, S. and Melfos, V., 2011. The Geochemistry of Carbonate-Replacement $\mathrm{Pb}-\mathrm{Zn}-\mathrm{Ag}$ Mineralization in the Lavrion District, 
Attica, Greece: Fluid Inclusion, Stable Isotope, and Rare Earth Element Studies, Econ. Geology, 106, 619-651.

Deer, W.A., Howie, R.A. and Zussman, J., 1966. Rock-forming minerals, non-silicates, 532-672.

Grasemann, B., Schneider, D.A., Stockli, D.F. and Iglseder, C., 2012. Miocene bivergent crustal extension in the Aegean: evidence from the western Cyclades (Greece), Lithosphere, 4, 23-39.

Katsikatsos, G., 1977. La structure tectonique d' Attique et de l' ile d' Eubee, Proceedings of VIth Coll. on the Geol. of the Aegean Reg., Athens 1977, (I.G.M.E. Publ.), V/1, 211-228.

Katsikatsos, G., 1990. Geology of Greece, Athens, 451 pp. (in Greek).

Lekkas, S. and Lozios, S., 2000. Tectonic structure of Mt. Hymittos (Attica-Greece), Annales Géologiques des pays Helléniques, 38, 47-62.

Lepsius, R., 1893. Geologie von Attica. Ein Beitrag zur Lehre von Metamorphismus der Gesteine, Berlin Zeitschr. F. parkt. Geol., 4, 196-592.

Marinos, G. and Petrascheck, W., 1956. Laurium. I.G.M.E. Geol. Geoph. Res., V/1, 247 pp.

Menant, A., Jolivet, L., Augier, R. and Skarpelis, N., 2013. The North Cycladic Detachment System and associated mineralization, Mykonos, Greece: Insights on the evolution of the Aegean domain, Tectonics, 32, 433-452, doi: 10.1002/tect.20037.

Papanikolaou, D., 1986. Geology of Greece, Eptalofos publications 240 pp. (In Greek).

Rice, A.H.N., Iglseder, C., Grasemann, B., Zamolyi, A., Nikolakopoulos, K.G., Mitropoulos, D., Voit, K., Muller, M., Draganits, E., Rockenschaub, M. and Tsombos, P.A., 2012. A new geological map of the crustal-scale detachment on Kea (western Cyclades, Greece), Austrian Journal of Earth Sciences, 105, 108-124.

Skarpelis, N., 2007. The Lavrion deposit (SE Attica, Greece): geology, mineralogy and minor elements chemistry, Neues Jahrbuch fïr Mineralogie Abhandlung, 183, 22-249.

Skarpelis, N., Tsikouras, B. and Pe-Piper, G., 2008. The Miocene igneous rocks in the basal unit of Lavrion (SE Attica, Greece): petrology and geodynamic implications, Geological Magazine, 145, 1-15.

Seidel, M., Pack, A., Share, Z. and Seidel, E., 2005. The Kakopetros and Ravdoucha iron-oxide deposits, western Crete, Greece: fluid transport and mineralization within a detachment zone, Economic Geology, 100, 165-174.

Voudouris, P., Melfos, V., Spry, P.G., Bonsall, T., Tarkian, M. and Economou-Eliopoulos, M., 2008. Minealogy and fluid inclusion constraints on the evolution of the Plaka intrusionrelated ore system, Lavrion, Greece, Mineralogy and Petrology, 93, 79-110.

Voudouris, P., Melfos, V., Spry, P.G., Bonsall, T.A., Tarkian, M. and Solomos, Ch., 2008. Carbonate replacement $\mathrm{Pb}-\mathrm{Zn}-\mathrm{Ag} \pm \mathrm{Au}$ mineralization in the Kamariza area, Lavrion, Greece: Mineralogy and thermochemical conditions of formation, Mineralogy and Petrology, 94, 85-106.

Whitney, D.L. and Evans, B.W., 2010. Abbreviations for names of rock-forming minerals, American Mineralogist, 95, 185-187, doi: 10.2138/am.2010.3371 185. 